What drives the career choice among engineers? A case in Malaysian manufacturing plant

Choo, Ling Suan $\square$

Universiti Sains Malaysia, Penang, Malaysia(choolingsuan@yahoo.com)

Norsiah, Mat

Universiti Utara Malaysia, Kedah, Malaysia (norsiah@uum.edu.my)

Tan, Lin Im

Universiti Utara Malaysia, Kedah, Malaysia (linim.tan@gmail.com)

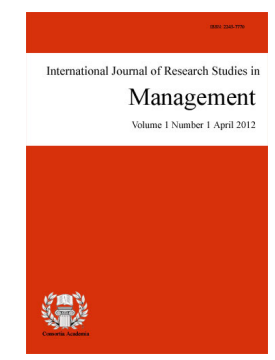

ISSN: $2243-7770$ Online ISSN: 2243-7789

OPEN ACCESS

\title{
Abstract
}

This empirical study was conducted to determine factors that influence the career choice among engineers in a Malaysian manufacturing plant. Subjects of this study were taken from engineers in one of manufacturing plant in Malaysia. As hypothesized, the results suggest that perceptions of person-job fit and financial rewards are significant factors that influence the career choice of engineers. Contrast to our hypothesis, influence from family members does not have any impact in determining the career choice among engineers. Interventions in attracting more engineers to remain in their career path and limitations of the study are also being discussed in the paper.

Keywords: career choice; perceptions of person-job fit; financial rewards; family influence; career path 


\section{What drives the career choice among engineers? \\ A case in Malaysian manufacturing plant}

\section{Introduction}

Careers are a major component of modern life. In today's highly competitive environment, life revolves around work which provides people a sense of purpose, challenges, self-fulfillment, and of course, income. Apart from that, careers also provide a source of identity and creativity, as well as of status and access to social networking. The careers of engineers have been the subject of a series of studies that have in common the implicit assumption that manufacturing sector of a country is dependent upon, at least in part, the quality of its professional engineers (Keenan, 1994). With the technical capability, it grants the organization to secure its survival in the global market environment (Alberto, 2000). At the same time, the growth in technology has made the engineers to play an even more critical role as they are accounted for the survival and growth of the company.

In the case of Malaysia - a developing nation in Southeast Asia, the electronics industry has started in Malaysia since 40 years ago. Dating back to year 1972, a few multinational companies have setup their manufacturing plants in Penang free-trade zone area. However, till to date industry demand for engineers has far exceed its supply. In fact, lack of engineering talents has been an ongoing issue in Malaysia for many years. According to the statistics from the Malaysia Ministry of Higher Education, there were 59,471 degree holder graduated from local universities in year 2007 but only 9,426 were graduated from engineering field (Ministry of Higher Education, 2007). On the other hand, statistics estimated that Malaysia would need about 200,000 engineers by year 2020 - a nation embarking on knowledge-based economy. Unfortunately, presently the statistics shows that only about 60,000 engineers are available in the country (The Star, 2009). This demand-supply gap amounting to almost 70 percent of shortage of engineers will definitely hinder the country's development and sluggish Malaysia from realizing its vision of 2020.

This perturbing phenomenon is particularly evident among engineers in manufacturing industry. Despite the shortage of engineering graduates, many of those graduated as engineers prefer to venture into non technical career. To counter this phenomenon, some manufacturing companies have come out with the dual career system for their engineers. According to this system, engineers are given a choice to either continue in the technical career or move to the management career. Technical career is where engineers continue as the individual technical contributor, involved in technical specialization. Managerial career is where engineers choose to become the people's manager (Maimunah, 2003). In this light, Allen and Katz (1986) pointed that there are some shortcomings of the dual career system. First, technical and managerial careers have a different attractiveness for organization members. For instance, due to the cultural reasons society may be perceived a lower prestige to a technical career than to a managerial advancement. Second, in some circumstances, even some organizations put technical positions on the same level as managerial positions in terms of prestige, salary and status, the technical positions may still perceived as lacking the vital ingredient of power. Third, the generalized practice whereby technical promotions sometimes are tends to be slower than managerial position. Lastly, there were some individuals, rewarded for a particular technical achievement by promotion into the managerial ladder, discover that they have neither liking nor ability for management (Turpin \& Deville, 1995)

Bearing the shortcomings of dual career system in mind, coupled with the increase of demands for engineers in Malaysia, it seems to be timely to study what are the underlying factors that could influence the career choice of an engineer. To the researcher knowledge, empirical study focuses on the career choice among engineers in the Malaysia manufacturing context is limited. To address this issue, this study seeks to identify the plausible determinants of career choice among engineers in the context of Malaysian manufacturing. Specifically, this study focuses on engineers in Research and Development (R\&D) department for two main reasons. First, R\&D 
engineers are widely recognized as a mean for manufacturing company in creating and sustaining their competitive advantage in the global marketplace. Second, the increasing of the dependency of organizations on technology, having competent $\mathrm{R} \& \mathrm{D}$ engineers and the effective management of $\mathrm{R} \& \mathrm{D}$ engineers in the organization is getting important (Alberto, 2000). With this, this study is attempted to focus on the determinants of career choice among R\&D engineers in Malaysia manufacturing context.

\section{Literature review}

\subsection{Career Choice Theories}

Career choice is defined as choosing one professional over another. According to Agarwala (2008), there are two conditions that need to be available in order for career choice to happen. Firstly, the other career option must be available and secondly is the individual preference. A review of past literatures in career management, organizational behavior and human resource management shows that there are three major career choice theories in explaining the factors that influence an individual career options namely: Holland's Trait Theory (Holland, 1985); Schein's career Anchor Model (Schein, 1978) and Social Cognitive Career Theory (SCCT) (Lent, Brown, \& Hackett, 1994).

Holland's Trait theory - suggests that individual career choice can be predicted by understanding the individual's interest, ability and needs (Chang, 2005). According to Margolis (2008) Holland trait theory was built base on the four assumptions:

1. People can be categorized into six different types which are a) realistic; b) investigative; c) artistic; d) social; e) enterprising; f) conventional

2. Occupational types can be divided into six categories: a) realistic b) investigative c) artistic, d) social, e) enterprising and f) conventional

3. Individual will choose for occupational environment that enable them to utilize their skills, express their attitudes and values

4. Individual's behavior is determined by the interaction between his personality and the characteristic of his environment.

However, this theory has been criticized for the lack of focus in cultural factors. It is also implies some cultural and gender bias because most of the females will fall into the artistic, social and conventional personality types (Margolis, 2008). Besides that, it does not take into consideration the interpersonal factors such as the influence from significant others around that individual as well as the external factor such as the economy situation and cultural perspective.

Career Anchor Theory - Career Anchor theory was introduced by Schein back in year 1978. Schein (1978) contends that individual career choice is guided by their career value. According to Schein (1978) individual career value is formed from the accumulation of individual needs, value and abilities with the life experience. In this theory, the term "Career Anchor" is used to represent the different career value that is critical in helping individual in making the career choice. Schein (1978) developed a 40-items questionnaire in order to help the individual to identify their own career anchor (Margolis, 2008). Schein (1978) suggests that each individual will only have one dominant career anchor because career anchor is made up from individual's life experience and prior career history which formed the individual career value. From the original 5 anchors identified, Schein (1978) further study extended the five anchors to eight career anchors that being used until today. The eight career anchors are: 1) technical/ functional competence; 2) managerial competence; 3) security and stability; 4) entrepreneurial creativity; 5) autonomy and independence; 6) service and dedication to a cause; 7) pure challenge; 8) lifestyle. However, the theory was criticized as it was derived base on a small pool of highly educated young 
Choo, L. S., Norsiah, M., \& Tan, L. I.

managers that have no difficulty to create career that consistent to their value (A. L. Y. Wong, 2007).

Social Cognitive Career Theory - Social Cognitive Career Theory (SCCT) was introduced by Lent et al. (1994) which derived from self efficacy theory by Bandura (1986). Bandura (1986) defines self-efficacy as the self-evaluation of their own abilities to complete a task. Applying self-efficacy theory, SCCT posits that individuals are more likely to pursue and be successful in occupations for which they have high self-efficacy (Lent et al., 1994). SCCT postulates that, individual prefers to pursue occupations that they believe will result in positive outcomes (e.g., gainful employment, self-satisfaction, and admiration (Lent et al., 1994). SCCT focuses on the inter-relationship among the various personal, environmental and behavioral variables which was assumed to impact performance outcome, career interest and choice. This theory has two level of theoretical analysis. First level is focus on cognitive variables (e.g. self-efficacy, outcome expectations, and goals) that allow individual to control their career development. In the second level analysis, this theory adds contextual variables and physical attributes and others (e.g. gender, ethnicity, social supports, and barriers) that will influence the career interest which eventually influence the career choice (S. C. K. Wong \& Liu, 2010). There are a few advantages of SCCT. First, social cultural factors were being considered in the SCCT. Second, SCCT includes the cognitive elements that focus on self efficacy and outcome expectation. Third, it covers the contextual variables such as ethnic identity, family environment, learning experiences and others. SCCT is viewed as the most important career theory because of its extensiveness and the complexness of the theory.

\subsection{Factors Contributing to Career Choice among Engineers}

In the quest of uncovering the reasons for career choice among engineers, many studies have been conducted in different cultural contexts to determine the range of factors that influenced the career choices (Kyriacou, Benmansour, Coulthard, Hultgren, \& Stephens, 2002; Ozbilgin, Kusku, \& Erdogmus, 2005; Ozkale, Kusku, \& Saglamer, 2004). A careful examination of past literatures in the area of career choice support the notion in SCCT (Lent et al., 1994). Past empirical studies evidenced that career choice is likely to be determined by three plausible factors, namely (1) intrinsic factors (personal interest in job, work satisfaction); (2) extrinsic factors (the availability of the job, salary); (3) interpersonal factors (influence of people surrounding an individual) (Chang, 2005; Davis, 2009; Margolis, 2008; Sugahara, Hiramatsu, \& Boland, 2009; S. C. K. Wong \& Liu, 2010). In this study, researchers attempt to study the factors conceived by Carpenter and Foster (1977) in the Malaysian manufacturing industry. Carpenter and Foster (1977) proposed that career choice is a result of intrinsic factors, extrinsic factors and interpersonal factors. The perceptions of person-job fit stems from intrinsic factors, financial reward stems from extrinsic factor; while influence from family members stem from interpersonal factor.

\subsubsection{Perceptions of Person Job-Fit}

According to Saks and Ashforth (2002), perception of person job-fit is a critical element in deciding one's careers. Perceptions of person job-fit refers to the individual's perceptions of match between the individual and the job requirements of that specific job (Carless, 2005). In particular, Edward (1991) suggested that person-job (P-J) fit can be classified into demand-abilities perspective and needs-supplies perspective. According to the demand-abilities perspective, the fit of demand-abilities could be achieved when individuals bring sufficient knowledge, skills, and abilities (KSAs) to meet the job demand. For instance, students with good educational background in engineering are likely to choose engineering as their career. This is because they belief that they are capable of handling the engineering role in their future career. Empirically, study has evidenced that applicants who perceived a fit between their knowledge, skills and abilities and the job requirements are probably able to remain in the selection process and accept a job offer (Carless, 2005). On the other hand, the needs-supplies fit exist when the job offers the individual something that is compatible to their needs, preferences and desires. For instance, Beng (2004) asserted that an individual's decision to go into teaching job is driven by their perception of teaching and the value of the teaching job. In this vein, Holland (1985), asserted that satisfaction and performance are enhanced when the individual selects an occupation that is compatible with 
his or her traits and skills. Empirically, Saks, and Ashforth (2002) found that the perceptions of pre-entry person-job fit were related to individual job search behavior and career planning. Therefore, it is plausible to relate that the perceptions of person-job fit would positively associate with career choice among engineers. Therefore, we hypothesize that

$\mathbf{H}_{1}$ : Perceptions of person job-fit is positively associated with the career choice of an engineer.

\subsubsection{Financial Rewards}

Employees would not be motivated if they are given rewards that were not meeting their expectation (Kim \& Cha, 2000). Although expectancy theory suggests that rewards has difference attractiveness to each person (Lawler Iii \& Suttle, 1973), financial reward is the most common extrinsic factor that being called out in the career choice literature. According to Von Glinow (1988) financial rewards comprised of pay, fringe benefits, bonuses and so forth. In an empirical study conducted on the sample of professional groups (accountants, attorneys, engineers and physicians), Rosen, Paolillo, and Estes (1982) discovered that earning potential is one of the important factor that influences the selection of profession, besides the job satisfaction and the aptitude for subject matters. Likewise, Allen and Katz (1995) indicated that most of the technical workers prefer to work in management position as they perceived that management positions in an organization have more power, prestige, salary, and status. On the other hand, Kim and Cha (2000) reported that individual in R\&D profession with different career orientations exhibit different work-related outcomes and reward preferences. In their study, Kim and Cha (2000) revealed that technical-oriented R\&D professionals tend to be favor professional rewards such as opportunities to present research outcomes to peer professionals as to enhance their professional abilities as opposed to managerial R\&D professionals who valued career rewards that enhance personal career development such as promotion, job transfer, entrepreneurial opportunities and so forth. Nevertheless, it is plausible to relate that financial reward could be one of the underlying factors that determine the career choice among engineers. In harmony with previous studies, we posit that

$\mathbf{H}_{2}$ : Financial reward is positively associated with the career choice of an engineer.

\subsubsection{Influence from Family Members}

Influence from family members refers to expectation set by family members such as parents and siblings that would influence the career choice of an individual (Monica \& Kate, 2005). Past researches have empirically found that parents have an influence on their child's career choice. For instance, Rosen et al. (1982) contended that parental influence, peer influence and job satisfaction are more important to physicians than other professional groups such as attorneys, engineers, and accountants. Likewise, Monica and Kate (2005) conducted a survey among information technology students indicated that parental education and their choice of careers are the strong motivators for children's career choices in information technology field. Again, Agarwala (2008) who surveyed among the population within the management students in India concluded that fathers played the most significant role in influencing their child in making their career choice. Therefore, it is hypothesized that

$\mathbf{H}_{3}$ : Influence from family members is positively associated with the career choice of an engineer.

\section{Materials and methods}

Data for this study were collected from Research and Development (R\&D) engineers in one of the multinational manufacturing plants that based in Penang. As mentioned above, selecting R\&D engineers was deemed appropriate to test the hypothesized relationships due to the fact that $R \& D$ engineers are the most critical technical staff in manufacturing company. Before the formal survey, researchers conducted a pilot test by distributing 60 questionnaires to the $R \& D$ engineers in other company. A total of 36 questionnaires were received for reliability analysis. Researchers examined Cronbach's alpha of all construct to eliminate some items which Cronbach's alpha are below 0.70. The alpha coefficients of remaining items were above .70 . The 
remaining items in the questionnaires were used for analysis.

In the formal survey, researchers contacted the General Manager by mail to introduce the purpose and the courage of this study. After the company had agreed to participate, a listing of all the R\& D engineers in that company was obtained from the Human Resource Department. The list shows that there are a total of $1344 \mathrm{R} \& \mathrm{D}$ engineers in the company. Based on the sampling frame, those R\&D engineers with employment less than six months were excluded in the analysis. A total of 1338 engineers met this a priori specified cutoff. A total 302 of R\&D engineers was selected base on the simple random sampling method using the random number table. The reason simple random sampling is recommended is because it has the least bias as all elements in the population is given the equal chance to be selected as sample and it is the represent from the population compare to other sampling method and it makes it easier to estimate the accurate result (Sekaran, 2000). The sample size of 302 is considered as appropriate and able to represent the population (Cavana, Delahaye, \& Sekaran, 2001)

A self-administered questionnaire survey was used to collect the data for this study. A cover letter attached to each questionnaire explained the objective of the study was mailed to the 302 R\&D engineers. Respondents were assured of anonymity and confidential treatment of the answers. Completed surveys were returned directly to researchers in a sealed and pre-address envelope. There are a total of three sections in this questionnaire. Section A is to obtain demographic information about respondent such as gender, age group, organizational tenure. Section B consists of questions regarding the independent variables in this study which comprised of person-job fit, financial reward, and influence from family members. The last section in the survey is to measure the career choice which is the dependent variable of this study. The questionnaire items for person-job fit, financial rewards, and family influence were adapted from Aycan and Fikret-Pasa (2003). The questionnaire items for career choice were adapted from Watt and Richardson (2007) to fit into the context of this study. There were four items pertaining to the perceptions of person-job fit, four items pertaining to financial reward, there items pertaining to influence from family members and three items pertaining career choice. All items were measured on a 5-point Likert scale ranging from $1=$ strongly disagree to $5=$ strongly agree. By the cut-off date of data collection, a total number of 103 sets valid questionnaires were received from the participants. This represents a response rate of 34.1 percent.

\section{Results}

\subsection{Respondents' Profile}

As shown in Table 1, the respondents were predominantly from male employees (80.6\%) with only 20 $(19.4 \%)$ of them were female employees. From the respondents, 54\% of them are between 21-30 years old, about $40 \%$ of them were between 31-40 years old and the remaining was within 41-60 years old. Pertaining to the organizational tenure, $57.2 \%$ of the respondents have been in the job for less than five years while $32 \%$ of the respondents have been in the job for 6-10 years. Only minority $(10.6 \%)$ of them have been in the job for more than 10 years.

\subsection{Descriptive Statistics}

Means and standard deviations were obtained for all four variables- career choice, person-job fit, financial reward and influence from family members. Table 2 shows the mean score for all four variables ranging from 2.06 to 4.10 . The mean score for person job-fit was $4.10(\mathrm{SD}=.575)$. Meanwhile, the mean values for career choice and financial reward were $3.72(\mathrm{SD}=.721)$ and $3.25(\mathrm{SD}=.911)$ respectively. The variable of influence from family members was at the lowest with a mean of 2.06. $(\mathrm{SD}=.865)$

\subsection{Regression Analysis}

Regression analysis was used to examine how much variance in the dependent variable is explained by a set 
What drives the career choice among engineers? A case in Malaysian manufacturing plant

of predictors. The results are summarized in Table 3 . The $\mathrm{R}$ squared value indicates that $24.9 \%$ of the variance in career choice among the R\&D engineers can be explained by the three variables (person-job fit, financial reward and family influence) $(\mathrm{R} 2=.249 ; \mathrm{F}=10.925, p<0.01)$. From the coefficients analysis, also shows that person-job fit $(\beta=.449, p<0.01)$ and financial reward $(\beta=.194, p<0.05)$ has significant and positive effect on career choice among the R\&D engineers. Thus H1 and H2 are supported. However, contradicted with our expectation in $\mathrm{H} 3$, influence from family members does not have a significant effect on career choice among the $R \& D$ engineers $(\beta=-.100, p>0.05)$. Based on the beta values, the perceptions of person-job fit $(\beta=449)$ seems to have the strongest impact on the career choice among the R\&D engineers.

\section{Table 1}

Respondents' profile

\begin{tabular}{llcc}
\hline \multicolumn{1}{c}{ Demographic } & \multicolumn{1}{c}{ Category } & Frequency & Percentage $(\%)$ \\
\hline \multirow{2}{*}{ Gender } & Male & 83 & 79.6 \\
& Female & 20 & 19.4 \\
& $20-30$ years old & 56 & 54.4 \\
Age & $31-40$ & 41 & 39.8 \\
& $41-50$ & 5 & 4.9 \\
& $51-60$ & 1 & 1 \\
Organizational & $1-5$ years & 59 & 57.2 \\
Tenure & 6-10 years & 33 & 32.0 \\
& $11-15$ years & 7 & 6.8 \\
& $16-20$ years & 2 & 1.9 \\
\hline
\end{tabular}

Table 2

Descriptive analysis for variables

\begin{tabular}{lcc}
\hline \multicolumn{1}{c}{ Variable } & Mean & Std. Deviation \\
\hline Career choice & 3.72 & .72073 \\
Person-job fit & 4.10 & .57462 \\
Financial Reward & 3.25 & .91119 \\
Influence from family members & 2.06 & .86499 \\
\hline
\end{tabular}

Table 3

Results of regression analysis for person- job fit, financial reward, and influence from family members on career choice

\begin{tabular}{lc}
\hline \multicolumn{1}{c}{ Independent Variables } & Career Choice \\
\hline Person-job fit & $0.449^{* *}$ \\
Financial Reward & $0.194^{*}$ \\
Influence from family members & -0.100 \\
F Value & $10.925^{* *}$ \\
R Squared & 0.249 \\
\hline
\end{tabular}

Note. $* p<.05, * * p<.01$

\section{Discussions}

The result from regression analysis shows that career choice among engineers is influenced by the 
perceptions of person-job fit and financial reward. This finding is in harmony with Agarwala (2008) who found that skills, competencies, and abilities were the most important and significant factors influencing the career choice of Indian management students. Besides that, complying with the findings of Rosen et al. (1982), the result in this study also shows that financial reward have positive and significant impact on the career choice among engineers. Meanwhile, in contrast to the findings of Agarwala (2008) and Rosen et al. (1982), the result from this study shows that influence from family members does not have any significant effect on the career choice among engineers. The Social Cognitive Career Theory contends that the contextual variables such as social support may have influence on the career choice of an individual. This finding from this study seems does not support the tenet of Social Cognitive Career Theory (Lent et al., 1994). However, this result is in line with the survey result conducted by Sacre, Atman, and Shuman (1997). In their results, Sacre et al. (1997) indicated that parental pressures to study engineering did not vary substantially among students, with each group exhibiting relatively low responses for "family influences" to study engineering. Researchers believed that, this result may due to the fact that $41 \%$ of the total respondent has more than five years working experience. Based on their working experience, it could be that respondents are more relying on their personal encounter at work when decide on their career choice. As such, the influence from family members does not have any influence in their career choice.

With this finding, it is strongly recommended that the management to design the job scope for engineers to fit the knowledge, skills, and abilities of an engineer. In this case, direct manager plays an important role to ensure each engineer is given an appropriate job scope as to keep them motivated in their daily job. The job scope given should not be purely routine engineering task, it would be better to include some kind of job assignments to stretch the engineer's capability in problem solving. Besides that, this study also proved that financial rewards are effective in influencing the career choice of the engineers. Therefore, besides attracting new talents by promoting the challenging job nature, human resource management can also focus on promoting attractive compensation package to attract the potential engineering candidates such as pay, fringe benefits, bonuses and so forth.

\subsection{Limitations and suggestions}

There are few limitations in this study. First, there are only 103 respondents in this study due to time constraint. A larger number of respondents would be better to give a more accurate result. Second, the respondents were limited to a target population which is solely from a manufacturing company. Third, the gender of respondents in this study was not even. About 83 of the respondents were male employees while only 20 of the respondents were female employees. The low response from female engineers has limited this research to make a solid conclusion in term of gender differences in career choice. It would be good to if future studies repeat this study using a larger sample to validate the findings of this study. Besides that, cross-industrial studies would also be recommended to have better understanding on the study subject and generalization of the results.

\section{Conclusions}

Our research aims to investigate the determinants of career choice among R\&D engineers in the context of Malaysia manufacturing plant. After conducting the empirical survey, we found that perceptions of person-job fit and financial rewards are the two main factors that influence the career choice among the R\&D engineers. With a better understanding of the determinants of engineers' career choice, organizations can strategize to retain and attract more engineers. Nevertheless, to stay competitive and profitable in the long run, the company has to leverage its engineers' capability to enhance it technical competencies. The advance in technical competencies will eventually contribute to the profitability and success of the company. 


\section{References:}

Agarwala, T. (2008). Factors influencing career choice of management students in India. Career Development International, 13(4), 362-376. <http://dx.doi.org/10.1108/13620430810880844>

Alberto, P. (2000). Strategic career development for R\&D staff: A field research. Team Performance Management, 6(3), 52-62. <http://dx.doi.org/10.1108/13527590010731970>

Allen, T. J., \& Katz, R. (1986). The dual ladder: motivational solution or managerial delusion? $R \& D$ Management, 16(2), 185-197. <http://dx.doi.org/10.1111/j.1467-9310.1986.tb01171.x>

Allen, T. J., \& Katz, R. (1995). The project-oriented engineer: A dilemma for human resource management. $R \& D$ Management, 25(2), 129-140. <http://dx.doi.org/10.1111/j.1467-9310.1995.tb00906.x >

Aycan, Z., \& Fikret-Pasa, S. (2003). Career choices, job selection criteria, and leadership preferences in a transitional nation: The case of Turkey. Journal of Career Development, 30(2), 129-144. <http://dx.doi.org/10.1177/089484530303000203>

Bandura, A. (1986). Social foundations of thought and action: A social cognitive theory. Prentice-Hall series in social learning theory (Vol. XIII). Englewood Cliffs: NJ: Prentice-Hall, Inc.

Beng, H. S. (2004). Determinants of eaching as a career in the UK. Evaluation and Research in Education, 18(4), 213-241. <http://dx.doi.org/10.1080/09500790408668320>

Carless, S. A. (2005). Person-job fit versus person-organization fit as predictors of organizational attraction and job acceptance intentions: A longitudinal study. Journal of Occupational \& Organizational Psychology, 78(3), 411-429. <http://dx.doi.org/10.1348/096317905X25995>

Carpenter, P., \& Foster, B. (1977). The career decisions of student teachers. Educational Research and Perspectives, 4(1), 23-33.

Cavana, R. Y., Delahaye, B. L., \& Sekaran, U. (2001). Applied business research: Qualitative and quantitative methods. Australia: John Wiley \& Sons Australia Ltd.

Chang, A. J. (2005). Ethnic identity and social cognitive determinants of Korean-American career choices in the science and non-sciences domains. Purdue University Indiana.

Davis, N. L. (2009). Factors influencing career choice among students enrolled in a four-year tourism administration program Southern Illinois University Carbondale.

Holland, I. L. (1985). Making vocational choices (2nd ed.). Englewood Cliffs: NJ: Prentice-Hall.

Keenan, T. (1994). Undergraduate education and the career orientation of professional engineers: Comparison between individuals from enhanced engineering courses and those from conventional engineering courses. Journal of Occupational \& Organizational Psychology, 67, 153-172. $<$ http://dx.doi.org/10.1111/j.2044-8325.1994.tb00558.x>

Kim, Y., \& Cha, J. (2000). Career orientations of R\&D professionals in Korea. R\&D Management, 30(2), 121-138. <http://dx.doi.org/10.1111/1467-9310.00163>

Kyriacou, C., Benmansour, N., Coulthard, M., Hultgren, A., \& Stephens, P. (2002). Emerging issues in teacher supply and retention. Paper presented at the EConference of the Teacher Supply and Retention Project, University of North, London. .

Lawler Iii, E. E., \& Suttle, J. L. (1973). Expectancy theory and job behavior. Organizational Behavior and Human Performance, 9(3), 482-503. <http://dx.doi.org/10.1016/0030-5073(73)90066-4>

Lent, R. W., Brown, S. D., \& Hackett, G. (1994). Toward a unifying social cognitive theory of career and academic interest, choice, and performance. Journal of Vocational Behavior, 45, 79-122. $<$ http://dx.doi.org/10.1006/jvbe.1994.1027>

Maimunah, I. (2003). Men and women engineers in a large industrial organization: Interpretation of career progression based on subjective-career experience. Women in Management Review, 18(1/2), 60. $<$ http://dx.doi.org/10.1108/09649420310462334>

Margolis, J. (2008). The attrition of engineering gradueates: An exploratory study on influential career choice factors. Michigan.

Ministry of Higher Education. (2007). Retrieved January 20, 2010, from http://www.mohe.gov.my

Monica, A., \& Kate, M. K. (2005). Early determinants of women in the IT workforce: A model of girls' career choices. Information Technology \& People, 18(3), 230-259. $<$ http://dx.doi.org/10.1108/09593840510615860>

Ozbilgin, M., Kusku, F., \& Erdogmus, N. (2005). Explaining influences on career choice: The case of MBA students. International Journal of Human Resource Management, 16(11), 2000-2028. <http://dx.doi.org/10.1080/09585190500314797>

Ozkale, L., Kusku, F., \& Saglamer, G. (2004). Women in engineering education in Turkey. Paper presented at 
Choo, L. S., Norsiah, M., \& Tan, L. I.

the American Society for Engineering Education Annual Conference \& Exposition, Engineering Education Reaches New Heights.

Rosen, L. S., Paolillo, J. G. P., \& Estes, R. W. (1982). An empirical analysis of career choice factors among accountants, attorneys, engineers, and physicians. Accounting Review, 57(4), 785.

Sacre, M. B., Atman, C. J., \& Shuman, L. J. (1997). Characteristics of freshman engineering students: Models for determining student atrition in engineering. Journal of Engineering Education, April, 139-149.

Saks, A. M., \& Ashforth, B. E. (2002). Is job search related to employment quality? It all depends on the fit. Journal of Applied Psychology, 87(4), 646-654. <http://dx.doi.org/10.1037/0021-9010.87.4.646>

Schein, E. (1978). Career dynamics: Matching individual and organizational needs. Massachusetts: Addison-Wesley.

Sekaran, U. (2000). Research methods for business: A skill-building approach. New York: John Wiley and Sons.

Sugahara, S., Hiramatsu, K., \& Boland, G. (2009). The factors influencing accounting school students' career intention to become a Certified Public Accountant in Japan. Asian Review of Accounting, 55(22).

The Star. (2009). Retrieved April 20, 2009, from http://www.thestar.com.my

Turpin, T., \& Deville, A. (1995). Occupational roles and expectations of research scientists and research managers in scientific institutions. R\&D Management, 25(2), 141-157. $<$ http://dx.doi.org/10.1111/j.1467-9310.1995.tb00907.x>

Von Glinow, M. A. (1988). The new professionals: Managing today's high tech employees. Cambridge: MA: Ballinger Publishing Company.

Watt, H. M. G., \& Richardson, P. W. (2007). Motivational factors influencing teaching as a career choice: Development and validation of the FIT-choice scale. The Journal of Experimental Education, 75(3), 167-202. <http://dx.doi.org/10.3200/JEXE.75.3.167-202>

Wong, A. L. Y. (2007). Making career choice: A study of Chinese managers. Human Relations, 60(8), 1211-1233. <http://dx.doi.org/10.1177/0018726707081661>

Wong, S. C. K., \& Liu, G. J. (2010). Will parental influences affect career choice? Evidence from hospitality and tourism management students in China. International Journal of Contemporary Hospitality Management, 22(1), 82-102. <http://dx.doi.org/10.1108/09596111011013499> 